\title{
France's scientists rally to oppose Allègre's reforms
}

[PARIS] Plans by Claude Allègre, the French science minister, for a profound reform of the country's research system are hanging in the balance this week after a strong backlash from the scientific community.

The issue came to a head at an unprecedented meeting in Paris on Monday (14 December) of the 800-member National Committee for Scientific Research, the 'parliament' of the country's scientists which plays a major role in evaluating laboratories and administering recruitment.

The meeting attacked the reforms as "ill conceived" and overwhelmingly rejected the way in which Allègre, formerly the director of the Institut de Physique du Globe in Paris, has tried to impose them on the scientific community with minimum consultation.

The meeting was organized in large part as the launch of a national debate on science, felt by many scientists to be a necessary prerequisite for reforms, but repeatedly refused by Allègre. This move was backed by Catherine Bréchignac, director general of the Centre National de la Recherche Scientifique (CNRS), and senior CNRS officials. Hubert Curien, a much respected former Socialist minister of research, also endorsed the move as a "very good initiative" that "opened up the debate".

The plenary meeting of the committee two-thirds of whom are elected by scientists - was the first in its 50-year history to be convened by scientists themselves. The massive turnout of more than 700 members was prompted by what many scientists fear are plans to dismantle Europe's largest fundamental research agency, the 27,000-strong CNRS, and to increase central control over research (see Nature 395, 729-730; 1998).

The atmosphere in the packed amphitheatre of la Maison de la chimie was one of rebellion, reminiscent of the student meetings of 1968. Usually reserved middle-aged academics and research administrators battled for microphones. Vincent Courtillot, Allègre's representative at the meeting, was repeatedly heckled, jeered and laughed at as he defended his minister's actions and plans.

The committee's challenge stems partly from its desire to have a say in the reforms. Although it sees itself as the representative of the scientific community, it has been excluded from discussions by Allègre. The meeting signalled a new assertiveness on the part of the committee, which had been criticized by Allègre as rife with nepotism and bureaucracy.

The minister has sought to create alternative evaluation structures within his ministry. But the thrust of the meeting was that a group of officials is no substitute for the col-

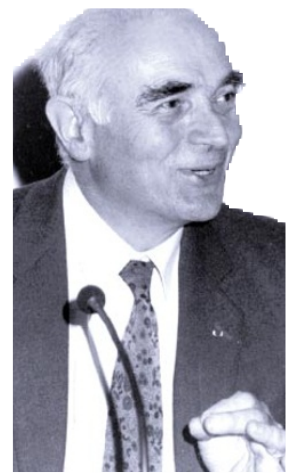

lective expertise of some 1,000 researchers, and that the reforms would fail unless they took into account the experience of scientists and a long-term view of research needs.

The resistance to Allègre's approach was illustrated by opposition from Curien: defended CNRS both CNRS and uniagainst Allègre's attack. versity researchers to his proposals to transfer much of the responsibility for the work of CNRS laboratories to the universities.

A succession of speakers accused the minister of risking the break-up of agencies such as CNRS that worked, while failing to address fundamental problems such as the weakness of university research.

Claude Cohen-Tannoudji, the 1997 Nobel prizewinner in physics, accused Allègre of naivety in trying to impose the US model of competitive research universities directly on France. He argued that the weaknesses of research in French universities that led to the creation of the CNRS in the 1930s were still alive and well, and that any reduction in the strength of the agency's laboratories would damage French science as a whole.

Curien also argued that French universities were in general no substitute for CNRS. "The universities are not ready yet; in 15 years perhaps, but for the moment, no."

Curien added that Allègre's attacks on the CNRS were unjustified, and that the major weaknesses of research - such as technology transfer and the mobility of researchers required a comprehensive analysis of the entire research and industrial landscape.

Bréchignac was equally critical. "Our minister, with his familiar brusqueness, but with conviction, tells us we need to 'move', and he is right," she said. "But we need to know where we are supposed to go."

The mood of the meeting was that scientists are keen to see improvements in the research system, but want these to be well thought out and introduced gradually by the research agencies themselves. For the moment, though, the situation appears deadlocked. Flush with its success in mobilizing the scientific community, the national committee appears in no mood to modify its opposition.

But Courtillot reaffirmed the ministry's intention to proceed with reforms, warning that "organizations that refuse to adapt are condemned to disappear".
DeclanButler

\section{UK set to back industrial spin-offs from research}

[LONDON] Proposals to encourage the commercial exploitation of scientific research in Britain were expected to be given high priority in a government white paper (policy document) on economic competitiveness, due to be published this week.

The white paper was expected to propose changes in the way in which the Department of Trade and Industry (DTI) spends its annual budget of $\mathfrak{E} 1$ billion (US $\$ 1.7$ billion). It was due to be unveiled by Peter Mandelson, Secretary of State for Trade and Industry, the cabinet minister responsible for science.

The measures are designed to help narrow the gap between the United Kingdom and its industrial competitors in terms of ability to benefit commercially from science and technology. Despite is position among the top few countries in terms of scientific output, the United Kingdom came thirteenth of 17 countries ranked in terms of their effectiveness in exploiting science in a survey by the Harvard Business School that was released last week.

Since taking up his post in a cabinet reshuffle earlier this year, Mandelson has been keen to find ways of encouraging partnerships between industry and the academic community, turning universities "from ivory towers into business partners".

For example, he is known to be enthusiastic about the Teaching Company Scheme run by the Engineering and Physical Sciences Research Council, which provides financial support to graduates working in companies on projects supervised jointly by the companies and universities. The scheme is expected to receive extra backing in the white paper.

Faraday Partnerships, which aim to improve the interaction between the science, engineering and technology base and industry, may also gain government support for their expansion plans.

Industry was hoping for changes to the tax system to make it easier for high-tech start-up companies to raise venture capital. And Mandelson has said he is keen to promote clusters of science-based businesses near universities.

Some of these proposals are likely to be financed by a reorganization of DTI funding of business initiatives. Rather than providing more broad-based regional aid, the department is keen to target funds on clusters of high-tech, 'knowledge based' industries

The white paper follows a statement last month by the Chancellor of the Exchequer, Gordon Brown, that the government is considering offering a tax credit for small and medium sized companies yet to make a profit (see Nature 396, 100; 1998). Natasha Loder 